Article

\title{
Employment Diversification as a Determinant of Economic Resilience and Sustainability in Provincial Cities
}

\author{
Marcin Bogdański
}

check for updates

Citation: Bogdański, M

Employment Diversification as a Determinant of Economic Resilience and Sustainability in Provincial Cities Sustainability 2021, 13, 4861. https:// doi.org/10.3390/su13094861

Academic Editor: Adam P. Balcerzak

Received: 10 March 2021

Accepted: 22 April 2021

Published: 26 April 2021

Publisher's Note: MDPI stays neutral with regard to jurisdictional claims in published maps and institutional affiliations.

Copyright: (C) 2021 by the author. Licensee MDPI, Basel, Switzerland. This article is an open access article distributed under the terms and conditions of the Creative Commons Attribution (CC BY) license (https:// creativecommons.org/licenses/by/ $4.0 /)$.
Faculty of Economics, University of Warmia and Mazury, 10-719 Olsztyn, Poland; marcin.bogdanski@uwm.edu.pl; Tel.: +48-89-523-43-30

\begin{abstract}
Differentiated response of selected economies to the global economic crisis caused by the collapse of the real estate market in the United States has drawn the attention of economists to the concept of economic resilience. At the same time, once again, it showed the importance of analysing and creating suitable conditions for sustainable development. Resilient economies are less exposed to the risk of economic crises or slowdowns, which is vital for ensuring stable incomes and high level of living standards. Therefore, the presented analysis was aimed at evaluating the level of economic resilience of provincial cities in Poland in relation to the situation on their labour markets. For this purposes, selected measures of the variation in the distribution feature (e.g., coefficient of variation) and the degree of structure diversification of the examined feature (Amemiya's index) were used. Subsequently, using correlation analysis, the research determined whether any relationships could be observed between the investigated variables. The results of the research indicate that for provincial cities sub-regions in Poland, a statistically significant, moderate negative correlation could be observed between the degree of employment structure diversification in 2009 and the scale and scope of the collapse in the number of employed persons in subsequent years. This suggests that a high level of employment diversification restricted the level of economic resilience in this case.
\end{abstract}

Keywords: economic resilience; employment diversification; labour market; sustainability

\section{Introduction-The Research Background}

The increasing economic globalisation has made modern economies at the national, regional and local level increasingly interdependent. Any changes or impulses occurring in one economy relatively quickly change the conditions in which other economies operate. Globalisation is accompanied by rapid scientific and technological progress and increased competition. This results in a significant increase in the turbulence of the economy, with a growing number of shocks and distortions changing the dynamics and structure of economic processes.

The global economic crisis that started in 2008 provides a good example illustrating the growing interdependence of economies. Negative impulses from the US economy triggered by the real estate crash within a short period of time caused a decline in economic activity in many economies worldwide [1] (pp. 75, 76), [2] (p. 3). The consequences of this crisis and of the measures taken to overcome it are still visible in selected countries and regions, such as public debt and high unemployment, with the greater share of women among the unemployed [3] (p. 3).

At the same time, at the regional level, some economies have been less affected by the global slowdown than others. Some of them have relatively quickly returned to a fast and stable economic growth path. It has drawn researchers' attention to the concept of economic resilience and regional sustainability. This relatively new concept, derived from the physical and natural sciences, helps to understand how individual economies respond to and recover from the experienced shock [4,5]. At the theoretical level, the concept of economic resilience makes it possible to identify the causes of the different course of 
economic processes, especially in the face of negative external shocks such as crises, natural disasters and social unrest. It also allows for the identification of factors stimulating its growth, thus making it possible to reduce the scale and scope of the negative economic and social impact caused by these distortions.

In view of the expected global economic slowdown caused by the COVID-19 pandemic [6-10], the question of the level of economic resilience of provincial cities in Poland seems justified. Given the great importance of these centres in Poland's socio-economic system, it can be assumed that the economic processes taking place in them will also have a significant impact on the scale and length of distortions experienced by the entire national economy. Considering the specificity of the Polish economy the conclusions drawn from the presented analysis might be important to better understanding of factors determining local and regional economic resilience in fast developing economies.

The aim of the presented analysis was to determine the level of employment diversification as one of the factors affecting the economic resilience of provincial cities. The results obtained were confronted with the data presenting the scale and scope of fluctuations on the labour markets of the analysed cities. It allowed to verify the thesis that a high level of economic diversification is an important stimulus of economic resilience. The measures used to achieve the research objective were, among others, the Index of Economic Diversification proposed by E. Amemiya and the coefficients of variation of the employment for the period of 2010-2018.

Considering the subject of the paper, it should be emphasised that the situation on the regional labour markets and its changes depend on various factors, and not only on those related to the level of employment diversification. They include, among others, the structure of production, changes in the demand and supply of labour and demographic factors. Their mutual, long-term influence was the cause of a different reactions of regional labour markets in the period of the economic transformation in Poland after 1989. At the same time, it may also be the cause of different dynamics of employment changes as a reaction to external shocks observed today.

The transition of the Polish economy from a centrally planned to an economy based on free competition and a market allocation of resources was associated with a large decrease in labour demand and an increase in unemployment rate, especially in those regions where agriculture played a relatively large role in the production structure. This mainly concerned the areas of the present voivodships: Zachodniopomorskie (with capital in Szczecin), Warmińsko-Mazurskie (Olsztyn), Kujawsko-Pomorskie (capital in two citiesBydgoszcz and Toruń) and, to a lesser extent, Podlaskie (Białystok), Lubelskie (Lublin) and Podkarpackie (Rzeszów) [11] (pp. 12-15). These regions still are characterised by a relatively high share of agriculture in the structure of GDP and value added, however, at present, this sector is much more competitive, productive and efficient. This, combined with the fact that it produces basic goods with lower income elasticity of demand, makes these voivodships slightly more resistant to slumps in external demand [12,13]. Similar, although on a smaller scale, effects of transformation processes were observed in regions with a relative dominance of traditional manufacturing, especially light industry. This concerned, in particular, such provinces as Łódzkie (Łódź), Lubuskie (two capitals-Gorzów Wielkopolski and Zielona Góra) and Dolnośląskie (Wrocław) [11] (pp. 12-15).

In the case of such voivodeships as Mazowieckie (Warszawa), Wielkopolskie (Poznań), partly also Ślaskie (Katowice), Dolnoślasskie (Wrocław) and Pomorskie (Gdańsk), the decline in demand for labour, and thus also fluctuations in the unemployment rate, after 1989 was clearly smaller. It was conditioned by a more competitive and modern production structure, where services and relatively modern branches of industry were, and still are, more important. Nowadays, these regions are also characterised by a much higher flexibility of employment than those in which agriculture plays an important role [ibid.].

What is important, greater volatility of labour markets in case of these regions results primarily from cyclical factors shaping the demand for labour (employment rate). It was observed by different researchers in different periods of time [14] (pp. 235-242); [15] 
(pp. 245-261); [16] (pp. 260-270). Importantly, the demand for labour grew particularly fast in the abovementioned regions during the economic recovery, hence one could observe greater fluctuations in employment in the periods of dynamic economic growth than in the periods of economic downturn. This, in turn, could have been caused by the specific structure of production, dominated by services and modern industrial products, i.e., goods characterised by high income sensitivity of demand and thus more susceptible to fluctuations in the economic situation.

On the other hand, the lower flexibility of regional labour markets in less developed voivodships, with a greater importance of agriculture and traditional industry, was also partially conditioned by factors on the supply side of the labour market-lower economic activity rate and lower labour resources [15-17]. The reasons for this include the faster aging of the population in these areas, the outflow of workers to more developed regions, a higher percentage of people entering early retirement and greater difficulties in finding a job (a significant percentage of long-term unemployed), especially at the beginning of the transformation systemic [18] (pp. 10-14).

Similar conditions also explain the greater volatility of unemployment rates and employment levels if we compare the economy of Poland and other more developed countries, such as the United States. A higher level of competitiveness, a more modern production structure and a greater volatility of global demand in the latter economy translate into a greater scale of fluctuations observed on the labour market during periods of economic change [19] (pp. 33-36).

The paper is divided into five parts. After the introductory part, the author presented the basic theoretical considerations on the concept of economic resilience and its importance to local and regional economies and their sustainable development. Then, the research hypothesis and methods were described followed by the presentation of the research results. The article ends with a summary and conclusions.

\section{The Notion of Economic Resilience and Its Determinants}

One of the hallmarks of the modern economy is its volatility and instability. The growing importance of technological innovations in social and economic life, the tightening of the level of competition and the development of economic globalisation contributed to an increase in demand volatility and significantly shortened the horizon of decisions made by enterprises. As a result, the number and frequency of demand and supply shocks, which affect economies, generating many negative social and economic effects, also increased. This, combined with the increasingly visible problem of global ecosystem imbalance, contributed to the development of the concept of sustainable development. Its implementation, in practice, would make possible to ensure a permanent and stable balance between the three spheres of human activity—social, economic and environmental. One of the threads of the discussion on sustainable development concerns the concept of economic resilience.

In a general sense, economic resilience is understood as the response of the system to a specific stimulus or shock or as the ability to avoid and manage natural and anthropogenic risks [20] (p. 16), [21] (p. 2), [22] (p. 524). In the research context, the term is used to describe the relationships occurring in the observed entity during and after the interference.

Although the concept of resilience has a fairly long research tradition, and while it is a good tool for analysing complex socio-economic systems especially at the macroeconomic level [23], it has long been overlooked by economists especially with respect to the regional analytical perspective. It was only the events of the recent global economic crisis that made this theory increasingly popular. Hence, economic resilience is a relatively new term. In view of the above, but also because the concept draws on different scientific disciplines and refers to different aspects of the system operations, it is understood and defined in various ways. Some approaches directly refer to the original, engineering method of defining and analysing resilience, while others involve a newer ecological concept. There are also 
attempts to combine both of these approaches within the idea of economic adaptation resilience [24] (p. 2015), [25] (p. 2).

According to the traditional, engineering approach, an urban or regional economy is characterised by economic resilience if it is able to recover from the shock. What matters, above all, is the speed with which the economy returns to its initial state or growth path Nevertheless, as Drobniak [26] (p. 50) observes, the concept of resilience defined in this way raises substantial doubts. If the resilience of a system, including an economic system, means the ability to return to the pre-existing equilibrium, it is difficult to consider it as development. Furthermore, if the given economy was on a negative growth path or if this growth was characterised by a predominance of negative socio-economic consequences, a return to the old growth path would not be desirable.

Economic resilience under the environmental approach relates primarily to the amount of disruption that the economy can absorb before it begins to change its form or function. According to Walker, Holling, Carpenter and Kinzing, economic resilience is the ability of a system to absorb disruptions and reorganise in the course of change to maintain essentially the same function and the same identity [27] (p. 2). There is no single point of equilibrium and no single path of economic growth in this approach, but several possible ones. What is more, they may evolve constantly under the influence of new external conditions as well as phenomena and processes occurring within the system. The concept of resilience is therefore similar to the notion of Schumpeter's creative destruction-the process of reorganising and restructuring the economy through innovation and innovative solutions [28] (p. 1437).

The characteristics of economic resilience can be measured with the use of macroeconomic indicators relating to business performance. These include, above all, changes in production volumes and changes in employment levels [29] (p. 590). With this aim in mind, it is important to use the data on the scale of employment changes as they better reflect the social consequences of economic shocks [30] (p. 39). This is because the employment level is returning to the values observed before the shock and recession with a greater delay. The results of selected research [31] (p. 470) suggest that the cycle of changes in the unemployment rate from maximum to minimum values after the shock is 4.8 years, while the corresponding time for changes in production volume is 1.9 years.

The literature on the subject includes numerous publications and analyses aimed at determining the level of economic resilience and its determinants with regard to selected territorial units. Most of these publications concerned the resilience of cities or regions during the global economic crisis of 2008-2012 and several years after its end [32] (p. 1766), [33] (pp. 419-432), [34] (pp. 267-287), [35] (pp. 203-224). An interesting review of results obtained in selected research in this area can be found, among others, in Drobniak and Tóth [20] (pp. 123-125), [5] (pp. 71-72). The above studies show that a diverse structure of production and employment makes an important determinant of economic resilience. It is relevant for at least three reasons [36] (p. 91):

(1) It can be a factor in preventing the lock-in of the economy on one development path

(2) Diversification allows better transfer and dispersal of external shocks in different directions (sectors and branches) of the economy, contributing to a faster economic recovery and faster adaptation to changed conditions. This is also confirmed by the analyses of Nazarczuk, Umiński and Jurkiewicz [37] (p. 830);

(3) A high rate of economic growth alone is not sufficient to ensure an adequate level of economic resilience. What is more important is the rapid and effective transformation of the economy, e.g., by adjusting the structure of production to new conditions and reinforcing scientific and technological innovation. This is possible just because of the diverse employment structure.

\section{Aim, Methods and Data Sources}

The presented analyses were aimed to determine the level of employment diversification as one of the factors affecting the economic resilience of provincial cities and its 
impact on the scale and scope of fluctuations in the number of employees during the global economic crisis. Confirmation or exclusion of such a relationship will give rise to a discussion on the conditions for the economic resilience of cities in Poland, especially in view of the expected economic turbulence caused by the coronavirus pandemic.

Based on the literature review, the research hypothesis has been put forward assuming that a high level of employment diversification stimulates the economic resilience of cities, thus limiting the scale and duration of employment decline during periods of economic downturn.

The achievement of the research objective and the verification of the hypothesis required specifying the level of employment diversification. E. Amemiya's IED index was used for this purpose, as a measure particularly often used in research on the urban economic base.

This index is calculated according to the following Formula [38] (p. 41):

$$
\mathrm{IED}=\sum_{i=1}^{m} \frac{m}{m-1}\left(\frac{Z i R j}{Z R j}-\frac{1}{m}\right)^{2},
$$

where IED—index of economic differentiation, $m$-number of business activities (Polish Classification of Business Activities (PKD) sections) used in the analysis (19), ZiRjemployment in business activity " $i$ " in region $j$ and $Z R j$-total employment in region $j$.

The IED assumes values from 0 to 1 , but in the presented analyses, the obtained results were multiplied by 1000 , which enabled their presentation in a more comprehensible form. Low IED values indicate the existence of a diverse structure of employment and production and vice versa. The literature suggests that if IED $<250$, the employment structure is considered to be highly differentiated. Where $250 \leq$ IED $<500$ indicates a complex structure, and the value in the range of $500 \leq$ IED $<750$ indicates a relatively homogeneous employment structure. The IED $\geq 750$ values indicate a highly homogeneous employment structure [38] (p. 42). This index was calculated for 2009.

Subsequently, coefficients of variation of the employment for the period of 2010-2018 were calculated as measures of the disturbances on local labour markets caused by the global economic crisis. Finally, in order to verify the research hypothesis, correlation coefficients between the data obtained in different sub-periods were calculated.

The research included all provincial cities in Poland. The choice of the research sample results from the importance of these centres in forming the social and economic potential of Poland. These cities perform the most important administrative and social functions with respect to regional communities and serve as the main focal points for product and production factor flows [39] (p. 413). At the same time, they generate about $1 / 3$ of all jobs in Poland and six of them (Warszawa, Kraków, Łódź, Wrocław, Poznań and Szczecin) create $25 \%$ of Polish GDP [40] (p. 25).

IED was calculated with the use of data showing the number of all employed persons in provincial cities in Poland by PKD sections. These data, originating from 2009 and 2018, were obtained from the Information Department of Statistics Poland (GUS). In other cases, the data originated from the GUS online statistical database (Local Data Bank). However, these data are only published at the level of NUTS3 statistical sub-regions. These subregions correspond to the boundaries of provincial cities only for the largest urban centres in Poland. In the case of other cities, they also include adjacent municipalities. In view of the above, the value of the IED for the Bydgoszcz-Torun sub-region was calculated as a mean of the IED calculated for Bydgoszcz and Torun.

The time frame of the study covers the period between 2009 and 2018 and was limited by the availability of comparable statistical data.

\section{Economic Resilience of Provincial Capital Cities}

Table 1 presents data showing employment in the analysed sub-regions in 2010-2018. Their analysis shows that the provincial capital cities experienced the effects of the economic slowdown after 2008 to a different extent. 
Table 1. Number of employed in selected NUTS3 sub-regions in Poland in 2010-2018 (in persons; the grey colour indicates the years in which the number of the employed decreased in relation to the previous year).

\begin{tabular}{|c|c|c|c|c|c|c|c|c|c|}
\hline \multirow{2}{*}{ SUB-REGION } & \multicolumn{9}{|c|}{ YEARS } \\
\hline & 2010 & 2011 & 2012 & 2013 & 2014 & 2015 & 2016 & 2017 & 2018 \\
\hline KRAKÓW & 376,706 & 381,679 & 389,932 & 397,626 & 412,226 & 423,449 & 445,910 & 463,822 & 479,441 \\
\hline KATOWICE & 327,292 & 333,578 & 331,423 & 333,504 & 335,228 & 336,732 & 341,476 & 347,607 & 350,445 \\
\hline $\begin{array}{c}\text { GORZÓW } \\
\text { WIELKOPOLSKI }\end{array}$ & 128,010 & 129,760 & 128,159 & 128,150 & 132,568 & 133,436 & 136,524 & 138,643 & 141,298 \\
\hline ZIELONA GÓRA & 195,039 & 194,805 & 191,484 & 192,143 & 197,925 & 201,161 & 207,324 & 213,098 & 216,426 \\
\hline POZNAŃ & 300,418 & 312,798 & 315,056 & 310,553 & 322,465 & 326,187 & 340,267 & 344,999 & 344,359 \\
\hline SZCZECIN & 153,243 & 154,674 & 154,758 & 155,214 & 157,356 & 159,855 & 164,276 & 172,102 & 174,211 \\
\hline WROCŁAW & 301,793 & 309,094 & 311,577 & 318,686 & 331,503 & 346,970 & 362,041 & 378,115 & 380,526 \\
\hline OPOLE & 210,085 & 212,563 & 210,311 & 212,597 & 216,798 & 219,883 & 225,390 & 228,108 & 233,489 \\
\hline $\begin{array}{l}\text { BYDGOSKO- } \\
\text { TORUŃSKI }\end{array}$ & 293,838 & 296,547 & 291,523 & 291,218 & 299,839 & 303,901 & 311,082 & 317,083 & 322,643 \\
\hline TRI-CITY & 303,579 & 307,118 & 308,123 & 314,501 & 320,098 & 328,323 & 345,313 & 369,391 & 374,420 \\
\hline OLSZTYN & 193,122 & 193,623 & 191,977 & 193,054 & 196,066 & 199,662 & 203,806 & 208,619 & 209,961 \\
\hline ŁÓDŹ & 304,642 & 299,663 & 299,245 & 299,615 & 305,987 & 307,691 & 314,896 & 327,251 & 336,774 \\
\hline KIELCE & 265,414 & 269,884 & 263,801 & 262,487 & 266,532 & 270,023 & 276,801 & 283,192 & 285,405 \\
\hline LUBLIN & 272,196 & 279,120 & 278,103 & 280,718 & 285,028 & 290,006 & 295,147 & 302,495 & 308,076 \\
\hline RZESZÓW & 242,974 & 249,125 & 248,311 & 250,358 & 257,451 & 260,335 & 269,221 & 280,755 & 286,659 \\
\hline BIAŁYSTOK & 169,982 & 172,705 & 169,861 & 171,130 & 174,287 & 176,970 & 182,998 & 187,585 & 192,980 \\
\hline WARSZAWA & $1,052,207$ & $1,075,157$ & $1,086,470$ & $1,078,536$ & $1,115,260$ & $1,154,001$ & $1,232,278$ & $1,286,651$ & $1,304,035$ \\
\hline
\end{tabular}

Source: GUS Local Data Bank, https:/ /bdl.stat.gov.pl/BDL/start (accessed on 13 August 2020).

With regard to four sub-regions (Kraków, Szczecin, Wrocław, the Tri-City sub-region) no decrease in employment was observed and the number of employed persons was higher in each subsequent year. Comparing the extreme years, it can be seen that the highest increase in employment in absolute numbers in this group was observed in Kraków (an increase of over 102 thousand employees) and the lowest was in Szczecin (20,968 persons). In absolute numbers, this represents an increase of $27.3 \%$ in Kraków, $26.1 \%$ in Wrocław, $23.3 \%$ in the Tri-City sub-region and $13.7 \%$ in Szczecin as compared to 2010. It is worth noting that these cities are the capitals of one of the developed regions in Poland [41] (pp. 10-12).

In other sub-regions, in at least one of the years under examination, a decrease in the number of employed was observed. However, both the scale and the moment of the employment decreases were varied. The earliest falls in employment could be observed in 2011 and they concerned the Zielona Góra sub-region and Łódź. They were relatively low and amounted to $0.12 \%$ and $1.63 \%$ of the labour force resources, respectively, as compared to the previous year. The number of sub-regions in which declines in employment were observed (11 such units were found) was the highest in 2012. In relative terms, the largest decrease in the number of employees in 2012 concerned the Kielce sub-region $(-2.25 \%$ as compared to the previous year) and the lowest was in the Łódź sub-region $(-0.14 \%)$ However, in the case of Łódź, it should be noted that this was the continuation of a negative trend, which started the year before. The last period in which a decrease in the number of employed was recorded was 2013. It concerned 5 of the 17 investigated sub-regions. However, the scale of observed decreases was already relatively small and in relative numbers ranged from $1.43 \%$ in Poznań to $0.01 \%$ in the Gorzów sub-region. Therefore, assuming that one of the basic manifestations of the economic crisis is a decrease in employment, it can be concluded from the above data that in the case of the largest cities in Poland, the crisis has been observed only in some of them and its duration is limited to the period of 2011-2013.

Considering the purpose of the conducted analyses, however, the key was to determine in which of the examined cities the employment fluctuations were relatively the highest (both during the economic crisis and later), how long the period of restoring the initial 
employment level was and whether the degree of diversity of the employment structure determined the scale of observed fluctuations in the number of the employed and the length of the downturn (Table 2). In order to better grasp the scale of variability in the number of the employed in the population under examination, the period of analysis was divided into two additional sub-periods-the years 2011-2013 (the period during which the negative effects of the economic crisis could be observed in the labour market) and the years 2014-2018 (the period of economic recovery).

Table 2. Degree of differentiation in the employment structure and the level of employment variability in selected sub-regions in 2010-2018.

\begin{tabular}{|c|c|c|c|c|c|}
\hline Sub-Region & $\begin{array}{l}\text { IED Value } \\
\text { in } 2009\end{array}$ & $\begin{array}{c}\text { Coefficient } \\
\text { of Variation } \\
\text { During } \\
2011-2013\end{array}$ & $\begin{array}{c}\text { Coefficient } \\
\text { of Variation } \\
\text { During } \\
2014-2018\end{array}$ & $\begin{array}{c}\text { Coefficient } \\
\text { of Variation } \\
\text { During } \\
2010-2018\end{array}$ & $\begin{array}{c}\text { The Length } \\
\text { of the } \\
\text { Recovery } \\
\text { Period }\end{array}$ \\
\hline KRAKÓW & 42.5 & 2.1 & 5.6 & 8.3 & 0 \\
\hline $\begin{array}{c}\text { KATOWICE } \\
\text { GORZÓW }\end{array}$ & 42.4 & 0.8 & 1.7 & 2.1 & 2 \\
\hline $\begin{array}{l}\text { WIELKOPOL- } \\
\text { SKI }\end{array}$ & 111.3 & 0.6 & 2.4 & 3.5 & 2 \\
\hline $\begin{array}{l}\text { ZIELONA } \\
\text { GÓRA }\end{array}$ & 59.3 & 0.8 & 3.4 & 4.3 & 3 \\
\hline POZNAŃ & 57.8 & 1.8 & 2.8 & 4.7 & 1 \\
\hline SZCZECIN & 50.0 & 0.5 & 4.0 & 4.6 & 0 \\
\hline WROCŁAW & 43.7 & 1.9 & 5.2 & 8.5 & 0 \\
\hline OPOLE & 59.6 & 0.6 & 2.6 & 3.7 & 1 \\
\hline $\begin{array}{l}\text { BYDGOSKO- } \\
\text { TORUŃSKI }\end{array}$ & 82.4 & 0.7 & 2.7 & 3.6 & 2 \\
\hline TRI-CITY & 48.5 & 1.3 & 6.2 & 7.7 & 0 \\
\hline OLSZTYN & 56.1 & 0.3 & 2.6 & 3.3 & 2 \\
\hline ŁÓDŹ & 69.1 & 0.7 & 3.7 & 4.0 & 3 \\
\hline KIELCE & 67.6 & 1.1 & 2.6 & 2.9 & 3 \\
\hline LUBLIN & 56.6 & 1.2 & 2.8 & 3.9 & 1 \\
\hline RZESZÓW & 61.5 & 1.1 & 4.2 & 5.5 & 1 \\
\hline BIAŁYSTOK & 66.2 & 0.7 & 3.7 & 4.4 & 2 \\
\hline WARSZAWA & 35.7 & 1.2 & 6.0 & 7.9 & 1 \\
\hline
\end{tabular}
2020).

Regardless of the period, the sub-regions in question did not show significant differences in the level of employment variability. The maximum value of the coefficient of variation concerning the number of the employed in the whole analysis period was observed in Wrocław. Nonetheless, its value (8.5\%) shows relative stability in the number of employed.

- After limiting the analysis only to the period of the economic crisis, i.e., 2011-2013, the highest variability in the number of employed was observed in the sub-regions of Krakow, Wrocław and Poznań. Interestingly, in the first two cities, the employment rate was increasing throughout the analysis period, so the changes observed were only the result of positive trends in local labour markets. In the sub-period in question, the lowest values of the coefficient of variation were observed in Szczecin (0.5\%), the Gorzów sub-region (0.6\%) and the Opole sub-region $(0.6 \%)$. It is therefore difficult to talk about the existence of significant differences between the sub-regions under consideration, despite the fact that in some of them, the changes taking place in the labour market were only of a positive nature (the number of people employed was constantly increasing) and, in others, a temporary decrease in the number of the employed was recorded.

- The examined population was characterised by noticeably greater differences in the horizontal variability of the number of employed persons in the second of the sub- 
periods of analysis (2014-2018), i.e., at a time of accelerated economic growth and related improvement in labour markets. The highest values of the coefficient of variation were found in the Tri-City sub-region $(6.2 \%$, with the average value for the entire examined population at 3.7\%), in Warsaw (6\%) and Krakow (5.65\%). On the other hand, the variability of the employment level in the years 2014-2018 was the lowest in the sub-regions of Kielce, Olsztyn and Opole (coefficient of variation at 2.6\%), Gorzów (2.4\%) and Katowice (1.7\%).

Although the relatively small differences in the dynamics and the scale of changes taking place in the labour markets of the investigated sub-regions do not give rise to categorical statements, two regularities can be observed. First of all, it seems that the sub-regions under examination were characterised by relatively similar economic resilience during the economic slowdown of 2011-2013. However, after 2013, some of them recorded significantly faster growth in employment, which proves the greater effectiveness in taking advantage of the opportunities generated by the economic recovery. This, in turn, may indicate significant differences in the level of competitiveness of the economies under investigation. Second, it seems that the level of variability in the number of the employed was lower in the case of the economies of smaller centres, which are also characterised by their relatively peripheral location in relation to large cities, considered to be growth poles of the national economy. The above conclusion is partially confirmed by the results of research carried out by R. Warżała [42] (pp. 184-187), who analysed the morphology and the course of business cycles in Poland on a regional basis. According to him, regions with a relatively modern production structure (especially those with a relatively small share of agriculture in GDP) were characterised by greater production fluctuations within the business cycle. At the same time, the period of economic recovery in these regions lasted longer and the scale of positive changes was greater. This may have been due to the greater specialisation of these areas in more competitive production sectors with greater added value (mainly market services) and greater potential for developing innovation and a knowledge-based economy [43] (pp. 129-132), [44] (p. 313).

Slightly greater differences between the regions can be observed in the length of the employment recovery period. For the purposes of this analysis, it is defined as the number of years that elapsed until the number of the employed returned to at least the same level as before the decrease. The literature assumes that the more economically resilient an entity is, the shorter the period of employment recovery will be. In view of the above, it can be assumed that the highest level of economic resilience was observed in Poznan, Warsaw and the sub-regions of Opole, Lublin and Rzeszów. For them, the period of returning to an employment level recorded before the crisis was 1 year. The recovery period was 1 year longer for Katowice, Gorzów, Bydgoszcz-Torun, Olsztyn and Białystok sub-regions. The longest (3-year) period of labour market potential recovery was observed in the Zielona Góra, Kielce and Łódź sub-regions. The recovery period was closely linked to the depth of the employment decline- the greater the decline, the longer the time to return to the initial number of the employed. Thus, in the case of sub-regions with the shortest recovery period, the minimum number of employed persons observed was on average $0.78 \%$ lower than in the last year before its decline. In the case of the second of the above-mentioned groups, the average decrease in employment was $1.24 \%$. However, the average decrease in employment was $-2.26 \%$ for sub-regions with the longest recovery periods.

The concept of economic resilience emphasises that one of the factors that can determine the depth of changes in employment levels during a period of economic crisis and the length of time needed to restore the original number of employed is the degree of diversity in the production and employment structure. Their high level usually translates into a high level of economic resilience (which means relatively small decreases in the level of economic activity after a negative shock and/or a relatively short period of economic recovery) and vice versa.

Analysing the IED values presented in Table 2, it can be observed that all examined entities were characterised by a relatively favourable situation in local labour markets-in 
all of them IED $<250$, which indicates a highly diversified employment structure. The lowest value of IED, i.e., the most diversified employment structure, in 2009 was observed in Warsaw (IED = 35.7 units). In turn, the highest value of IED was found in the Gorzów sub-region (IED $=111.3$, with the second-highest value of 82.4 in the Bydgoszcz-Torun subregion). Nevertheless, in this case, it is also possible to talk about a diversified employment structure and, indirectly, production structure.

In order to verify the research hypothesis, correlation coefficients between the IED value in 2009 and the coefficient of variation of employment in individual analysis periods were subsequently calculated. The values of the calculated correlation coefficients are provided in Table 3.

Table 3. Correlation coefficients between IED (Index of Economic Diversification) and the coefficient of variation in employment for selected sub-regions in 2011-2018.

\begin{tabular}{cccc}
\hline & $\mathbf{2 0 1 1 - 2 0 1 3}$ & $\mathbf{2 0 1 4 - 2 0 1 8}$ & $\mathbf{2 0 1 0 - 2 0 1 8}$ \\
\hline Correlation coefficient & -0.4356 & -0.5153 & -0.5068 \\
Significance level $(\mathrm{p})$ & 0.081 & 0.034 & 0.038 \\
\hline
\end{tabular}

Source: own work based on Table 2 data.

The values of correlation coefficients indicate that in each of the investigated periods, a moderate negative correlation and in two cases (periods 2014-2018 and 2010-2018), a statistically significant correlation between the variables studied was observed. Consequently, this shows that the more homogeneous a sub-region is in its employment structure, the lower is the level of its fluctuation in subsequent years. Importantly, a negative correlation was observed not only during the economic downturn in 2011-2013 but also during the recovery after 2013. This observation contradicts the theoretical analyses quoted earlier and the results of selected empirical analyses, which leads to the rejection of the accepted research hypothesis. However, it should be noted that, in fact, in 2009, each sub-region had a highly differentiated employment structure and the differences in the IED values were small, similarly to the differences in the coefficients of variation in the number of employed in subsequent years. Therefore, with a relatively small research sample, even small fluctuations in the direction and scale of changes in the level of employment of individual sub-regions, which may have resulted from a specific endogenous potential and a unique development trajectory, affected the obtained values of correlation coefficients.

It should also be borne in mind that the observed relationships may result from the production structure in the analysed regions. Some of the cities with relatively high IED values (i.e., a low level of employment diversification), such as Gorzów Wielkopolski, Bydgoszcz-Torun, Łódź, Kielce, and Białystok are the capitals of regions that, compared to the rest of the country, are characterised by a less competitive and modern production structure. Agriculture and traditional processing industries play a relatively important role in terms of their share of regional GDP and employment. In addition, as the results of the analyses cited earlier show, such regions may be characterised by greater stability of employment, especially in periods of economic slowdown, than areas with a predominant importance of services and production from high-tech industries.

Since a noticeable correlation existed in 2009 between the level of employment diversification in relation to sub-regions of provincial cities and the scale and variability of employment during the economic crisis, it is worth examining the IED value in the examined units on the eve of the expected economic downturn caused by the coronavirus pandemic. With this aim in view, the values of this indicator for 2018 are calculated and presented in Table 4. 
Table 4. IED values in selected Polish sub-regions in 2018.

\begin{tabular}{cc}
\hline SUB-REGION & IED \\
\hline KRAKÓW & 46.0 \\
KATOWICE & 36.3 \\
GORZÓW WIELKOPOLSKI & 94.4 \\
ZIELONA GÓRA & 56.6 \\
POZNAŃ & 52.9 \\
SZCZECIN & 48.3 \\
WROCŁAW & 40.4 \\
OPOLE & 53.5 \\
BYDGOSKO-TORUŃSKI & 66.8 \\
TRI-CITY & 42.6 \\
OLSZTYN & 55.5 \\
ŁÓDŹ & 66.6 \\
KIELCE & 65.9 \\
LUBLIN & 59.6 \\
RZESZÓW & 56.4 \\
BIAŁYSTOK & 69.2 \\
WARSZAWA & 41.9 \\
\hline
\end{tabular}

Source: own work based on Table 2 data.

The presented data show that the level of employment diversification of provincial cities in Poland in 2018 as compared to 2008 did not undergo significant changes. Again, in all cities, the index value was below 250 units. It should also be emphasised that the level of employment diversification increased in most of them. The exceptions were Warsaw, Kraków, Lublin and Białystok. However, the scale of the increase in the level of homogeneity of the labour structure was small. As a result, the average IED level decreased from 60.7 units in 2008 to 56.7 units 10 years later.

The groups of cities with the highest and lowest levels are similar to the situation of 2008. The cities with the highest IED values observed, i.e., with less diversified employment structure, include relatively small (compared to other surveyed units) urban centres, located mainly in the east of Poland. On the other hand, the most diversified employment structure was found for the largest cities in Poland with high economic potential and a relatively modern, competitive employment structure (with the largest percentage of persons employed in market services observed in those centres).

Therefore, it can be assumed that the effects of the economic slowdown caused by the COVID-19 pandemic will affect the economies of the largest and most economically developed Polish cities to the greatest extent (in the form of large employment fluctuations). In turn, such centres as Gorzów Wielkopolski, Toruń, Bydgoszcz, Łódź, Kielce, Lublin and Rzeszów are the least likely to experience turbulence on the local labour markets.

\section{Summary and Conclusions}

The category of economic resilience is the element of the economic potential of regions that can protect their economies against negative external shocks or reduce the scale and scope of the effects experienced as a result of these shocks. This primarily concerns a decline in the value of production output (GDP) and a decrease in employment. At the same time, the concept of economic resilience is blurred, defined in various ways and needs to be clarified. Consequently, there is no consensus over the factors stimulating economic resilience. However, a diversified production and employment structure is mentioned relatively often in this context. Understanding the economic importance of production and employment diversification might also contribute to increase in the long-term productivity and sustainability of regional economies.

The presented analyses aimed to determine whether, in the case of the provincial cities sub-regions, a relationship can be observed between the degree of employment diversification and their economic resilience. To achieve this objective, the IED for each of these regions was calculated and compared with the data on the change in employment during 
the global economic crisis caused by the property bubble bursting in the United States. The conducted analyses indicate that the relationship between the level of employment diversification and its variability during the economic downturn is negative. It contradicts the results of the aforementioned studies on economic resilience. Consequently, the research hypothesis assumed in the analyses should be rejected.

The results obtained, to a certain extent, may have been conditioned by the small diversity of the examined population in terms of the initial level of employment diversification. Furthermore, the question remains open as to the extent to which the observed differences in the scale and direction of changes in employment in the analysed sub-regions were conditioned by the sector structure of employment and other specific developmental conditions. Obtaining answers to these questions will determine the further course of the author's analyses.

Assuming that the relationships observed will also continue in the future, relatively large fluctuations in employment can be expected in Poland's largest and most developed cities in view of the expected economic slowdown caused by the coronavirus pandemic. However, the negative effects on local labour markets will be less severe for provincial cities in eastern Poland.

The basic condition for conducting an effective economic policy, both at the local and regional level, is to know the most important determinants of the course of economic processes. In this context, the conclusions from the presented research may constitute one of the premises determining the direction of government and local government authorities' activities to strengthen the economic resilience of selected areas of Poland. Importantly, however, these conclusions are not limited to just this one economy. Taking into account a similar level of economic development, similar institutional conditions and a similar direction and form of economic transformation, it can be assumed that in other Central and Eastern European countries, regional economic resilience in a similar way depends on the conditions in the labour markets. It gives a broader and more universal perspective on the discussion on factors influencing sustainable development and effective use of production factors.

Funding: This research received no external funding.

Institutional Review Board Statement: Not applicable.

Informed Consent Statement: Not applicable.

Data Availability Statement: Data on which study is based are available at Polish Statistical Office website https:/ /bdl.stat.gov.pl/BDL/start (accessed on 13 August 2020).

Conflicts of Interest: The authors declare no conflict of interest.

\section{References}

1. Nazarczuk, J.M. The impact of the world financial crisis on the economy of Poland and its regions. In Selected Aspects of Regional Development; Kisiel, R., Wojarska, M., Eds.; Fundacja “Wspieranie I Promocja Przedsiębiorczości na Warmii i Mazurach”: Olsztyn, Poland, 2013.

2. Ter-Mkrtchyan, A.; Franklin, A.L. Global Financial System Outcomes after 2008: A Longitudinal Comparison. Economies 2020, 8 , 24. [CrossRef]

3. Barba, I.; Iraizoz, B. Effect of the Great Crisis on Sectoral Female Employment in Europe: A Structural Decomposition Analysis. Economies 2020, 8, 64. [CrossRef]

4. Crescenzi, R.; Luca, D.M.; Milio, S. The geography of the economic crisis in Europe: National macroeconomic conditions, regional structural factors and short-term economic performance. Camb. J. Reg. Econ. Soc. 2016, 9, 13-32. [CrossRef]

5. Tóth, B.I. Regional economic resilience: Concepts, empirics and a critical review. Misc. Geogr. Reg. Stud. Dev. 2015, 19, 70-75. [CrossRef]

6. Pardal, P.; Dias, R.; Šuleř, P.; Teixeira, N.; Krulický, T. Integration in Central European capital markets in the context of the global COVID-19 pandemic. Equilib. Q. J. Econ. Econ. Policy 2020, 15, 627-650. [CrossRef]

7. Dias, R.; Teixeira, N.; Machova, V.; Pardal, P.; Horak, J.; Vochozka, M. Random walks and market efficiency tests: Evidence on US, Chinese and European capital markets within the context of the global Covid-19 pandemic. Oeconomia Copernic. 2020, 11, 585-608. [CrossRef] 
8. Kuc-Czarnecka, M. COVID-19 and digital deprivation in Poland. Oeconomia Copernic. 2020, 11, 415-431. [CrossRef]

9. Kufel, T. ARIMA-based forecasting of the dynamics of confirmed Covid-19 cases for selected European countries. Equilib. Q. J. Econ. Econ. Policy 2020, 15, 181-204. [CrossRef]

10. Korzeb, Z.; Niedziółka, P. Resistance of commercial banks to the crisis caused by the COVID-19 pandemic: The case of Poland. Equilib. Q. J. Econ. Econ. Policy 2020, 15, 205-234. [CrossRef]

11. Kwiatkowski, E. Bezrobocie regionalne w okresie przedakcesyjnym w Polsce, Acta Universitatis Lodziensis. Folia Oeconomica 2003, 170, 439-455.

12. Bogdański, M. Regional development in Poland. In Teaching Crossroads: 12th IPB Erasmus Week; Silva, E.M.P., Clarisse Pais, L.S., Eds.; Instituto Politécnico de Bragança: Bragança, Portugal, 2017; p. 1330.

13. Piszcz, N.; Klonowska-Matynia, M. Uwarunkowania Rozwoju Społeczno-Gospodarczego Głównych Regionów w Polsce. Wybrane Aspekty. Zeszyty Naukowe Wydziału Nauk Ekonomicznych 2018, 1, 259-286.

14. Kwiatkowski, E.; Kucharski, L. Dekompozycja zmian bezrobocia w krajach Europy Środkowo-Wschodniej w latach $2004-2013$. Studia Prawno-Ekon. 2014, 93, 223-244.

15. Kucharski, L. Decomposition of unemployment in Poland according to voivodeships in the years 2013-2018. Studia Prawno-Ekon. 2020, 115, 243-263. [CrossRef]

16. Cicha-Nazarczuk, M. Dekompozycja zmian w stopie bezrobocia w ujęciu regionalnym. Studia Prawno-Ekon. 2015, 94, 257-272.

17. Tyrowicz, J.; Wójcik, P. Some Stylized Facts on Unemployment Dynamics in Transition. East. Eur. Econ. 2010, 48, 5-22. [CrossRef]

18. Kwiatkowski, E.; Kucharski, L. Long-term unemployment in Poland in the years 1995-2007, Comparative Economic Research. Cent. East. Eur. 2010, 12. [CrossRef]

19. Biernacka, P. Makroekonomiczne determinanty bezrobocia na przykładzie Polski i Stanów Zjednoczonych w latach $2000-2016$. Catallaxy 2016, 1, 31-38. [CrossRef]

20. Drobniak, A. Urban resilience and post-industrial city. In Urban Resilience Concept and Post-Industrial Cites in Europe; Drobniak, A., Ed.; Uniwersytet Ekonomiczny w Katowicach: Katowice, Poland, 2014.

21. Noy, I.; Yonson, R. Economic Vulnerability and Resilience to Natural Hazards: A Survey of Concepts and Measurements. Sustainability 2018, 10, 2850. [CrossRef]

22. Xu, H.; Li, Y.; Wang, L. Resilience Assessment of Complex Urban Public Spaces. Int. J. Environ. Res. Public Health 2020, 17, 524. [CrossRef]

23. Roszko-Wójtowicz, E.; Grzelak, M.M. Macroeconomic stability and the level of competitiveness in EU member states: A comparative dynamic approach. Oeconomia Copernic. 2020, 11, 657-688. [CrossRef]

24. Modica, M.; Reggiani, A. Spatial Economic Resilience: Overview and Perspectives. Netw. Spat. Econ. 2014, 15, 211-233. [CrossRef]

25. Rota, S.F.; Bagliani, M.; Feletig, P. Breaking the Black-Box of Regional Resilience: A Taxonomy Using a Dynamic Cumulative Shift-Share Occupational Approach. Sustainability 2020, 12, 9070. [CrossRef]

26. Drobniak, A. Resilience and Hybridization of Development of Small and Medium Towns in Poland. Olsztyn Econ. J. 2019, 14, 47-62. [CrossRef]

27. Walker, B.; Holling, C.S.; Carpenter, S.R.; Kinzig, A. Resilience, adaptability and transformability in social-ecological systems. Ecol. Soc. 2004, 9, 5. [CrossRef]

28. Kakderi, C.; Tasopoulou, A. Regional economic resilience: The role of national and regional policies. Eur. Reg. Stud. 2017, 25, 1435-1453. [CrossRef]

29. Sensier, M.; Artis, M. The resilience of employment in Wales: Through recession and into recovery. Reg. Stud. 2014, 50, 586-599. [CrossRef]

30. Fratesi, U.; Rodríguez-Pose, A. The crisis and regional employment in Europe: What role for sheltered economies? Camb. J. Reg. Econ. Soc. 2016, 9, 33-57. [CrossRef]

31. Reinhart, C.; Rogoff, K. The aftermath of financial crisis. Am. Econ. Rev. Pap. Proc. 2009, 99, 466-472. [CrossRef]

32. Fröhlich, K.; Hassink, R. Regional resilience: A stretched concept? Eur. Plan. Stud. 2018, 26, 1763-1778. [CrossRef]

33. Wichowska, A. Shrinking municipalities and their budgetary revenues on the example of the Warmian-Masurian Voivodeship in Poland. Oeconomia Copernic. 2019, 10, 419-432. [CrossRef]

34. Farelnik, E. Cooperation of slow cities as an opportunity for the development: An example of Polish National Cittaslow Network. Oeconomia Copernic. 2020, 11, 267-287. [CrossRef]

35. Wierzbicka, W. Socio-economic potential of cities belonging to the Polish National Cittaslow Network. Oeconomia Copernic. 2020 11, 203-224. [CrossRef]

36. Peng, C.; Yuan, M.; Chaolin, G.; Zhongren, P.; Tingzhen, M. A review of theory and practice of regional resilience. Sustain. Cities Soc. 2017, 29, 86-96. [CrossRef]

37. Nazarczuk, J.M.; Umiński, S.; Jurkiewicz, T. Foreign ownership as a neglected factor in regions' smart specialization exports. $J$. Bus. Econ. Manag. 2020, 21, 75-76. [CrossRef]

38. Knapik, W. Changes in the functional structure of cities in the Łódzkie Voivodship in 2000-2008. In Studies on the Economic Base of Cities and the Labour Market in the Łódzkie Voivodeship; Wójcik, M., Ed.; Zakład Geografii Regionalnej i Społecznej Uniwersytetu Łódzkiego: Nowy Sacz, Poland, 2010.

39. Walendziak, E.; Wojarska, M.; Jett, Q. Small Cities in the Development Policy of Waminsko-Mazurskie Voivodeship. Olsztyn Econ. J. 2018, 13, 411-424. [CrossRef] 
40. Bogdański, M. Evolution of the economic base and the economic growth of voivodship cities. Pr. Nauk. Uniw. Ekon. Wroctawiu 2018, 536, 21-38. [CrossRef]

41. Miłek, D. Spatial differentiation in the social and economic development level in Poland. Equilibrium 2018, 13, 487-507. [CrossRef]

42. Warżała, R. Business Cycles Variability in Polish Regions in the Years 2000-2016. Dyn. Econom. Models 2017, 17, 177-189. [CrossRef]

43. Wierzbicka, W. Information infrastructure as a pillar of the knowledge-based economy-An analysis of regional differentiation in Poland. Equilibrium 2018, 13, 123-139. [CrossRef]

44. Kijek, A.; Matras-Bolibok, A. Technological convergence across European regions. Equilibrium 2020, 15, 295-313. [CrossRef] 